\title{
Correction to: Unlocking the Value of Anti-TNF Biosimilars: Reducing Disease Burden and Improving Outcomes in Chronic Immune-Mediated Inflammatory Diseases: A Narrative Review
}

Mourad F. Rezk · Burkhard Pieper

Published online: September 11, 2020

(C) The Author(s) 2020

Correction to: Adv Ther (2020) 37:3732-3745

https://doi.org/10.1007/s12325-020-01437-4

In the original article, under the "Access to treatment" heading, there are incorrect text as" "Similarly, Razanskaite et al. [51] demonstrated that at the same time that costs were reduced following IFX biosimilar introduction, the number of treatments went up from a maximum of 100,000 vials/month to 140,000 vials/month." The correct text is as follows "Similarly, Razanskaite et al. [51] demonstrated that at the same time that costs were reduced following IFX biosimilar introduction, the number of treatments went up from a maximum of $\sim 350$ vials/month to $\sim 450$ vials/month."

Open Access. This article is licensed under a Creative Commons Attribution-NonCommercial 4.0 International License, which permits any non-commercial use, sharing, adaptation, distribution and reproduction in any medium or format, as long as you give appropriate credit to the original author(s) and the source, provide a link to the Creative Commons licence, and indicate if changes were made. The images or other third party material in this article are included in the article's Creative Commons licence, unless indicated otherwise in a credit line to the material. If material is not included in the article's Creative Commons licence and your intended use is not permitted by statutory regulation or exceeds the permitted use, you will need to obtain permission directly from the copyright holder. To view a copy of this licence, visit http:// creativecommons.org/licenses/by-nc/4.0/.

The original article can be found online at https://doi. org/10.1007/s12325-020-01437-4.

M. F. Rezk $(\bowtie) \cdot$ B. Pieper

Biogen International $\mathrm{GmbH}$, Neuhofstrasse 30, 6340

Baar, Switzerland

e-mail: mouradfarouk.rezk@biogen.com 